\title{
Public health emergency: social representations among managers of a university hospital ${ }^{1}$
}

\author{
Dirciara Barañano Souza² \\ Clarice Maria Dall'Agnol ${ }^{3}$
}

\begin{abstract}
Aim: to comprehend the social representations of public health emergencies among managers who experienced the Influenza A (H1N1) Pandemic of 2009. Method: a qualitative case study, with its theoretical and methodological framework based on the Theory of Social Representations. The data was obtained through the techniques of free association and semi-structured interviews, applied individually to managers who worked in different positions of the hierarchical management structure of the institution during the pandemic emergency, a total of 30 participants. Results: thematic content analysis resulted in the following categories: vulnerability, health protection, neglect - gray areas of the public sphere, and integrality. The social representations of public health emergencies attest to continuities that transit the overvalorization of negative discourses linked to the health/education public space, naturalization of the substantial character of the epidemic, and normative managerial action. However, the defense of ongoing education as a necessity associated with emergency management revealed possibilities for change in the technical-scientific perception of the management. Conclusions: to understand healthcare/ nursing workers as political beings, assuming responsibilities in the areas of the macro and micro policies of the State, the university hospitals and the work teams, is a pathway that is emerging for the management of emergencies.
\end{abstract}

Descriptors: Nursing; Health Management; Surge Capacity; Communicable Diseases; Influenza A Virus.

\footnotetext{
${ }^{1}$ Paper extracted from doctoral dissertation "Representações sociais de emergência de saúde pública entre gestores em um Hospital Universitário", presented to Escola de Enfermagem, Universidade Federal do Rio Grande do Sul, Porto Alegre, RS, Brazil.

${ }^{2} \mathrm{PhD}$.

${ }^{3} \mathrm{PhD}$, Associate Professor, Escola de Enfermagem, Universidade Federal do Rio Grande do Sul, Porto Alegre, RS, Brazil.
}

Corresponding Author:

Clarice Maria Dall'Agnol

Universidade Federal do Rio Grande do Sul. Escola de Enfermagem

Rua São Manoel, 963

Bairro: Rio Branco

CEP: 90620-110, Porto Alegre, RS, Brasil

E-mail: clarice@adufrgs.ufrgs.br 


\section{Introduction}

Public health emergencies have become a topic of great relevance in contemporary society, faced with the current health problems that emerge in a context of globalization restructuring and that expose populations to threats arising from the increased circulation of people, the rapid flow of products and services, as well as old and new diseases. Based on contextualized risk analysis regarding health events(1) that can spread internationally, the public health emergency concept has been discussed in the literature, especially in relation to infectious events that occur in the form of outbreaks and epidemics ${ }^{(2)}$. It should be noted that public health emergencies are not confined only to infectious agents. They also include risk factors with the potential of spreading diseases such as environmental disasters and chemical or radio-nuclear threats, whether they are accidental or intentional(1). However, in this study the approach to the theme was provided based on the concrete experience of the influenza A (H1N1) pandemic of 2009.

Therefore, without dwelling on situations of influenza pandemics, we sought to answer the question: which social representations of public health emergencies are expressed in contemporary times from the perspective of managers of a university hospital that experienced the influenza $A(H 1 N 1)$ pandemic in 2009 ? The general aim of the study was to comprehend the social representations of public health emergencies among these managers, considering their quotidian construction from the perspective of the reified and consensual universes expressed in mechanisms of objectification and anchoring(3).

Although public health emergency situations caused by infectious agents have been registered in the public health field for centuries, they still cause threats and insecurity due to the changing pattern of infectious diseases and the transmission dynamics of their agents ${ }^{(4)}$. At the beginning of the XXI century, the swine influenza, which reached pandemic status through the influenza A ( H1N1) virus, constituted a challenge to managers and workers of the health area due to its lack of a clear pattern of behavior, impacting on the managerial decisions(5). Even though this is an old field, there is still a process of discovering the possibilities for organizing the strategies for managing these emergency situations(6). This is a challenge for the healthcare services, not only in developing countries such as Brazil, but also in the developed countries. For this reason, the concern with health problems resulting from infectious diseases has returned to the agendas of the governments.

When it comes to challenge for the healthcare services, the need is felt to give life to these services. This is because they only exist because of the people who plan, organize and operationalize them, strengthening the relationship between subject and object, the focus of the Moscovician theory ${ }^{(3)}$. Therefore, the theory highlights a subject who, in his/her relationship with the world, constructs the world as well as him/herself. Given these considerations and the realization of the strategic position of the university hospitals for this study as integrator centers of the care network in the Brazilian National Health System (SUS), it is understood that when the focus of study is on the social insertion of public health emergencies, this is likely to contribute for the production of knowledge for healthcare/nursing, for expanding circumscribed approaches to eminently epidemiological aspects of emerging and reemerging infectious diseases ${ }^{(7-8)}$. It is understood that the results can be converted into support for the restructuring of management, detection and response strategies for current and future emergencies, with implications for nursing for its expressive management/care practice in the hospitals spaces $^{(9)}$.

\section{Method}

This is a qualitative case study, with its theoretical and methodological framework based on the Theory of Social Representations ${ }^{(3)}$, using as the research field a public university hospital in southern Brazil, which is part of the hospital network of the Ministry of Education. The physical structure of the hospital includes 190 beds, providing $100 \%$ SUS care ${ }^{(10)}$. The institution has in its hierarchical managerial structure, workers employed in formal management positions and workers who respond informally for a hospital unit, integrating to form the management team.

The study participants totaled 30 managers of the university hospital studied. The selection was intentional, including the workers who occupied managerial positions in the formal hierarchy of the institution during the influenza A (H1N1) pandemic in 2009 and those considered strategic for the coordination of this public health emergency. There were no exclusion criteria for the selected employees.

Data collection was performed individually between June and September 2011, in appropriate meeting rooms 
in the workplace, with the date and time previously scheduled. The procedure, with audio recording, began with the technique of free word association, performed through the evocation of words. As the inducer of the associations, the expression 'public health emergency in the influenza pandemic' was used. The following question was presented: what three words come to mind when you hear the term 'public health emergency in the influenza pandemic'? Soon after, they were asked to organize these three words, highlighting the two most significant or important. Next, the continuation of the data collection was carried out using the semistructured interview technique. In relation to the number of participants to be interviewed, the saturation criteria was followed, considering studies that indicate between 20 and 30 interviews are needed to reach this position ${ }^{(11)}$. First, eight managers of the central administration of the hospital were interviewed, corresponding to $26.7 \%$ of the total sample. This management group consisted of four nurses, one without a formal management position, 3 medical supervisors with formal management positions, two of them being professors, and one physician with an informal management position. According to the study design, they were asked to indicate other workers, considered to have been strategic in the coordination of the pandemic emergency, until the module of 30 interviews was complete. There was a homogeneous numerical division between the study participants with regard to the status of formal managers and informal managers.

After verbatim transcription of the information, thematic categorical analysis was performed as proposed by Laurence Bardin(12), followed by the prospect of studies indicating that the themes, in their design, appear as the center of consciousness based on experience, where the "thematic structure somehow coincides with the work of objectification" of the representation. Thus, the affective, cognitive and social elements that organize and favor the emergence of the themes, indicate the second central point in the understanding of the social representations, anchoring ${ }^{(3,13)}$. Initially the technique of free association was explored, then, using the Microsoft Excel 2010 program, the products of the evocations were organized into frequency lists, the order of appearance of the three words evoked, and the importance attributed to them by the participants, since this stimulated the organization of the two most important words. The analysis of the results obtained from this test was deepened through associations or confrontation with the meanings explored in the interviews.
The project was presented to the research ethics committee of the institution proposed for the study and was approved under number 19985 . Consent was sought from the participants through the signing of the Terms of Free Prior Informed Consent, requesting permission to audio record the statements of the interviewees. To maintain the anonymity of the information, the statements were transcribed and identified by the letter ' $E$ ' followed by increasing numbers, according to the chronological order of performance $(E 1, E 2, \ldots)$.

\section{Results and Discussion}

The analysis of the information obtained in the word association test and in the interviews resulted in four thematic categories: Vulnerability, health protection, neglect: gray areas of the public sphere, and integrality, which are presented below.

\section{Vulnerability}

The concrete experience of the managers with a public health emergency situation, created by the influenza $\mathrm{A}(\mathrm{H} 1 \mathrm{~N} 1)$ pandemic, constituted an disturbing threat. A threat with the bitter taste of uncertainty and the intimate pain of helplessness faced with not knowing what should be done. There was an association of the emergency with the vulnerability thematic category. This category is configured as the crystallization of the social representation of the object, which is the embodiment of what was abstract for the subjects, i.e., through the thoughts and speech of the study participants, anchored in the elements of their reality ${ }^{(3)}$. The social representation of the public health emergency presents itself anchored in key elements related to fear, panic, ignorance, insecurity, unusual character, contagion, divine punishment, death and information. These themes were reinforced in the word association test, highlighting fear and panic as having higher frequencies and greater importance attributed by the participants.

The feeling of fear that was expressed in the statements of the interviewees inspired by the emergency experience caused by the H1N1 flu pandemic in 2009 heralded signs of recalling memories of the quotidian of epidemics that terrorized the past, such as the 1918 Spanish flu. We know the Spanish flu that they had in the past, and all those previous ones, right?[...] the fear was great. It was our first experience of participating in a pandemic, a worldwide experience (E8). The memory of the Spanish flu shows up as a pathway to deal with what at that moment presented itself as a little understood 
event. This constitutes an attempt to escape the state of bewilderment and disorientation, "organizing the phenomenon into a system of familiar and functional categories for the individuals, which are easily available in the memory, naming and classifying it according to the links that this maintains with its social insertion"(14).

The managers situated the emergencies at a safe distance from the comprehensible domains, invoking a response to the rational insistence on dealing with what was presented in reality, but unconsciously had an inexplicable and negative force. In a certain way, the subjects remained linked to the historic legacy of the explanation of epidemics being due to a divine plan. In the speech of the subjects a request for absolution could be seen, justified by the virtuous conduct of working and helping, with this revealing a connection between the pandemic emergency and the idea of punishment.

For the majority of the managers the media played a significant role during the H1N1 emergence, both as a source of panic and as a source of information. In the opinion of some authors there was a certain sensationalism in the reporting of deaths by the media, causing panic and favoring failures in the control of the pandemic ${ }^{(15)}$. While there are elements of stability, linked to the memory of the epidemic diseases(16), anchoring the representation of public health emergencies, the information theme gives visibility to one of the most important characteristics of our time, the speed, the acceleration of time. The constant transformations give the feeling of a permanent delay in relation to the present, which needs to be thought out carefully if one wants to distance oneself from the pure opinion (doxa) that defines the meaning of our time.

\section{Health protection}

The health protection category contained one of objectifications of the representation about the public health emergency, anchored in elements related to prevention, control, isolation, biosafety, diagnosis, treatment and regulation actions. In the word association test, the following expressions were highlighted: prevention due to its higher frequency, appearance and importance order attributed by the subjects, and treatment, which appeared among the 150 evocations as the second most mentioned word. The conversion of the idea of public health emergency into health protection, as a crystallized image that can be comprehended and transmitted by the subjects, has the prevention theme as its main anchoring. When making reference to health protection, which can be both individual and collective, it is worth distinguishing it from prevention, since the specificity of protection lies in the nature and magnitude of the defenses and not in the intensity of the risks, as is the case with prevention ${ }^{(17)}$. Prevention is one of the actions of health protection. The subjects spoke of public health emergencies in a way closely linked to individual means of protection, because the explanations regarding preventing were often the adoption of the safe act attributed as the responsibility of the workers.

During an emergency such as the influenza pandemic, the use of personal protection equipment (PPE) refers to the preservation of the health of the workers as a way for them to remain safe while carrying out their activities. It cannot be forgotten that the risk of exposure is one of the factors that affect the willingness to work during a pandemic ${ }^{(5)}$. Therefore, the emphasis on PPE emerges as a concrete managerial action, as a strategy to lessen the absenteeism and support to keep the service functioning to meet the demand. Conversely, prevention as anchoring, may also reveal, among its meanings, a transfer of the responsibility for possible failures of these measure of protection to the workers. "The explanation of the exposure of workers to risks that make them more susceptible to contracting diseases, due to procedures and attitudes that do not take into consideration safe practices and the correct use of PPE are heavily disseminated in society, mainly among the workers themselves, favoring the production of a culpable consciousness"(18).

Control is another important anchoring that supports the arguments of the subjects linked to prevention, in the sense of avoiding (preventing) the propagation of the disease, establishing a link with the notion of isolation. Seen as a legacy of public health and traditional medicine, which also organize the body of knowledge of public health surveillance, this control often leads to opacification, in that the management decisions will have implications for people, with a valorization of rules directed toward diseases and the environment(19). Although these organizations operate in the unconscious field, they offer elements that hide the subjects involved and that emphasize the intervention in risk situations as if they messed with the lives of the people. The question of prejudice was raised, the people reacted a bit. They thought it was prejudice, that we [the institution] were not treating them well. If we put a mask on them, they felt assaulted, the separation assaulted them. They did not understand well (E13).

When studying social representations the fact that they are historically constructed must be considered(20). Therefore, it becomes important to consider that the 
speech of the subjects showed signs of the legacy of clinical logic, based on the traditional biomedical model, which seeks a standard pattern of operation and the standardization of behavior. With this, the expression "lack of standardization", evoked in the word association test and which featured greatly in the interviews, was sought.

\section{Neglect: gray areas of the public sphere}

The emergence of the influenza pandemic was also understood by the study subjects in line with the difficulties that the health sector is facing. Often reported in the media and discussed in healthcare and nursing studies(21), these difficulties are marked by a lack of working conditions in public hospitals, by the overcrowding of emergency departments and the financial problems of the hospital healthcare institutions. The care-management demand arising from the pandemic intensified these problems, causing a disaccommodation of negative feelings associated with the chaotic scenario of health that in the day-to-day of the managers often seem silenced in an orderly routine. In this context, the subject objectified the public health emergency concept in the image of 'neglect' in direct relationship with the public context, anchored in various themes such as chaos, public health, public service and others that converged into the lack of infrastructure, staff planning, commitment to the public sphere, valorization of the worker and qualification of the managers and of the healthcare network. In the word evocation test, the themes chaos and public health were highlighted, due to presenting themselves as the first evocation and being identified as the most important.

It is important to note that the public health emergency was represented by a specific group, involved with the management, in a specific space: a university hospital. Therefore, together with the crisis in the healthcare sector, the managers experienced and comprehended the pandemic in connection with the difficulties also experienced in the teaching in public health in Brazil. We are like this [silence] with many deficiencies. As always, the healthcare and the education, always [pause]. There are still many difficulties (E13).

The statement reinforces an ever present denial, linked to health and education(22), which can generate an atmosphere unreceptive to innovations, even if perceived by the subjects as necessary. They express the reality of the emergency services and the capacities of the hospitals to respond to public health emergencies, which in fact is far from the organization idealized by the
WHO through the International Health Regulations ${ }^{(1)}$. Among other difficulties, the poor conditions for action to which the workers end up being (re)submitted brings out a feeling of devalorization. If the manager is also a worker, it is thought that devalorization also occurs in the relationship that should be established for the interviewee, as a worker and manager of the work processes. This pathway includes the representation of the fluidity of the action for the care of public health emergencies, because it is in this place that the workers are disqualified.

\section{Integrality}

The challenge of integrating the efforts of the healthcare system to support the emergency pandemic encouraged the opening of spaces for dialogue between professionals and services involved with the problem. As common content of the speech of the subjects, aspirations and values emerged strongly linked to the notion of integrality, favoring the transformation of the complexity and novelty of the emergency caused by the influenza pandemic into a concrete and significant image familiar to the subjects. As an element that composes the concept of social representation, "the images do not separate from the creative potential of the objects and subjects, which reorganize, constitute and are constituted into infinitely new forms"(14). Thus, when reporting their experiences during the pandemic emergency, the subjects had already formulated a representation of this object, which is to say that stimulus and response formed together ${ }^{(20)}$.

In this construction, the public health emergency was anchored in elements such as: organization, integration, solidarity, social responsibility, ongoing education, and teaching-care distancing. In the word evocation test, the prominent themes were knowledge, due to its greater frequency, order of appearance and importance attributed by the managers, and organization, being the third most mentioned word prominent among the 150 evocations. The organization theme was present in the interviews permeating the actions of the subjects for managing the emergency. Through the lens of Moscovician theory "everything that makes us act, fulfill a function and positions us in social relations, follows a dominant social representation, i.e., one that has a higher degree of anchoring and therefore legitimacy and sharing in the social environment"(3). Thus, the notion of organization emerges as the most influential anchoring element for the image of integrality. In the speech of the subjects, organization gains emphasis when it is 
linked to the need for articulation between services and actions, which brings together that of anchoring with one of the meanings of integrality, i.e., the organization of the services and of the health practices. In this sense, integrality is presented as a way of organizing the services in order to assimilate new needs, which must be considered in a comprehensive way(23). It can be said that one of the complexities of public health emergencies is in their dynamics, due to the capacity for rapid change in the epidemiological pattern within the same event, incorporating requirements that need to be absorbed by the services.

The expectations of the interviewees regarding the technical knowledge converged so that there was greater investment in ongoing education actions, adding to this theme the words update and education evoked by the subjects. The defense of ongoing education as a necessity associated with emergency management indicates possibilities for change in the predominantly technical-scientific perception of the management. In line with this theme the controversy over the gap between teaching and care stood out in the interviews, manifested in the lack of communication between the university and the hospital during the pandemic emergency.

\section{Conclusions}

The social representations of public health emergencies from the perspective of managers in a university hospital delineate elements that permit the understanding of the complexity involved in the management of this theme. They permit the visualization of the concepts that underlie the representations, providing subsidies for the analysis of the symbolic forms that constitute the representations and that gain strength through strategies that transit the overvalorization of negative discourses linked to the public space of health and education, and the naturalization of the substantial and incurable character of the epidemic and of the technical-normative managerial action. However, if the representations attest to continuities, they also indicate important movements that could mean advances in the construction of management strategies in healthcare and nursing to deal with the problem, which are committed to the proposal of integral healthcare and approach the principles of the Brazilian National Health System. It should be mentioned as limitations of the study that the social representations of public health emergencies, because they were studied based on the experience of the flu pandemic, bring with them symbolic interpretations related to influenza, and related to the context of a public university hospital and the explicit characteristics of the managers of this specific space. The results obtained, although they do not allow a generalization of the findings, present an overview of the challenges in the management of public health emergencies, from the perspective of healthcare services that integrate health and education into their space, which can be a starting point for further studies or to form generalizations.

Among the pathways indicated in the study, as open possibilities, it is highlighted that to think from the positivist standpoint responds to an expectation, however, from the point of view of the theory of uncertainty it can make a discovery absolute that is momentary and therefore valid at the time. Social representations are not conscious constructs and therefore can influence the public health emergency management practices that do not correspond to the rational will of the group. We emphasize the importance of health/nursing workers assuming commitments and responsibilities in the areas of macro and micro policies of the State, the university hospitals, and the work teams, understanding themselves as political beings.

\section{References}

1. Organização Mundial de Saúde. International Health Regulations (2005) [Internet]. 2005 [acesso 25 mar 2012]. Disponível em: http://www.who.int.

2. Carmo EH, Penna G, Oliveira WK de. Emergências de saúde pública: conceito, caracterização, preparação e resposta. Estud Avançados. 2008;22(64):19-32.

3. Moscovici S. Representações Sociais: investigações em psicologia social. Petrópolis: Vozes; 2003.

4. Teixeira MG, Costa MCN, Viana I, Paim JS. Vigilância em saúde: é necessária uma legislação de emergência? Rev Direito Sanitário. 2009;10(2):126-44.

5. Goldim JR. Bioética e pandemia de influenza. Rev HCPA. 2009;29(2):161-6.

6. Souza DB; Dall'Agnol CM. Social representations of health surveillance among workers. Rev. Latino-Am Enfermagem. 2008;16(3):452-7.

7. Trigueiro JVS, Nogueira JÁ, Sá LD, Palha PF, Villa TCS, Trigueiro DRSG. Tuberculosis control: decentralization, local planning and management specificities. Rev. Latino-Am. Enfermagem. 2011;19(6):1289-96.

8. Ferreira ACS, Suarez-Mutis MC, Campos MR, Castro CGSO. Primary health care in municipalities at high risk for malaria. Rev. Latino-Am. Enfermagem. 2011;19(6):1281-8. 
9. Moura GMSS, Magalhaes AMM, Dall'agnol CM, Juchem BC, Marona DS. Leadership in Nursing: Analysis of the Process of Choosing The Heads. Rev. Latino-Am. Enfermagem. 2010;18(6):1099-106.

10. Hospital Universitário Dr. Miguel Riet Corrêa Júnior. Conheça o HU [Internet]. 2010 [acesso 10 jun 2012]. Disponível em: http://www.hu.furg.br.

11. Ghiglione R, Matalon B. O inquérito: teoria e prática. Oeiras: Celta Editora; 1997.

12. Bardin L. Análise de conteúdo. Lisboa: Edições 70; 2011.

13. Vignaux G. Cátegorisations et schématisations: dês arguments au discours. In: Dubois D. Ed. Sémantique et cognition. Paris: CNRS; 1991. p. 215-50.

14. Trindade ZA, Souza Santos MF, Almeida AMO. Ancoragem: notas sobre consensos e dissensos. In: Almeida AMO, Souza Santos MF, Trindade ZA, organizadores. Teoria das representações sociais: 50 anos. Brasília: TechnoPolitik; 2011. p.101-121.

15. Neumann CR, Azambuja MIR, Oliveira FA, Falk JW. Pandemia de Influenza A (H1N1): o que aprender com ela? Rev HCPA. 2009;29(2):92-9.

16. Nascimento DR, Gouvea G. O signo da culpa na história das doenças. $12^{\circ}$ Encontro Regional de História ANPUH-Rio. ST 14 - Ciências biomédicas, saúde e enfermidades em perspectiva histórica; 2008.

17. Freitas JD, Porto MF. Por uma epistemologia emancipatória da promoção da saúde. Trabalho Educ Saúde. 2011;9(2):179-200.

18. Possamai H, Guareschi P. Minha culpa, meu destino. In: Veronese MV, Guareschi PA, Organizadores. Psicologia do cotidiano: representações sociais em ação. Petrópolis: Vozes; 2007. p. 225-46.

19. Souza Campos GW. Saúde paideia. São Paulo: Hucitec; 2003.

20. Jodelet D. A fecundidade múltipla da obra "A psicanálise, sua imagem e seu público". In: Almeida AMO, Souza Santos MF, Trindade ZA, Organizadores. Teoria das representações sociais: 50 anos. Brasília: TechnoPolitik; 2011. p.199-223.

21. Lopes MMB, Carvalho JN, Backes MTS, Erdmann AL. Políticas e tecnologias de gestão em serviços de saúde e de enfermagem. Acta Paul Enferm. 2009;22(6):819-27. 22. Gomes RC. A visão de gestores e professores sobre as práticas de ensino e gestão no Hospital Universitário Walter Cantídio da Universidade Federal do Ceará [dissertação]. Fortaleza: Universidade Federal do Ceará; 2010.

23. Mattos RA. Integralidade e a formação de políticas específicas de saúde. In: Pinheiro $R$, Mattos RA,
Organizadores. Construção da integralidade: cotidiano, saberes e práticas em saúde. $4^{a}$ ed. Rio de Janeiro: IMS/ UERJ-CEPESC-ABRASCO; 2007. p.130-41. 